\title{
DR. BURHANUDDIN AL-HELMI: KEGIATAN NASIONALISME DAN POLITIK DI ZAMAN PENDUDUKAN JEPUN, 1940-1945
}

\author{
Mohamad Muzammil bin Mohamad Noor
}

\begin{abstract}
Dr Burhanuddin al-Helmi was an avid nationalist who felt very strongly about obtaining independence from the British. One of the more interesting aspects of Burhanuddin's political struggles was his ideas of Islam which he sought to inculcate in his struggles although he was viewed as a radical Malay with strong leftist leanings. This article examines Burhanuddin's political thoughts and activities during the Japanese Occupation of Malaya. His cooperation and activities with the Japanese military would also be examined. Burhanuddin's was given special treatment by the Japanese military administration and was appointed as a special advisor on Islamic affairs and Malay customs based in Taiping, Perak. This enabled him to obtain some experience in administration. Thus the Japanese Occupation of Malaya provided Burhanuddin with a good opportunity to pursue his political struggles. He hoped that the entry of the Japanese into Malaya would provide an opportunity for Malaya to obtain independence together with Indonesia. The Japanese Occupation invariably had a strong impact on Burhanuddin's political struggles and spirit of nationalism, and in a broader sense that of the Malay community and Malaya.
\end{abstract}

\section{Pengenalan}

Zaman Perang Dunia Kedua atau zaman pendudukan Jepun di Tanah Melayu yang bermula pada tahun 1941 telah membuka lembaran baru kepada Dr. Burhanuddin dalam perjuangan politiknya. Pada dasarnya, Dr. Burhanuddin seperti memberi kerjasama kepada pemerintah tentera Jepun melalui satu konsep yang diperkenalkan oleh pihak Jepun sebagai salah satu cara untuk mendapatkan kemerdekaan di tanah air masingmasing. Konsep yang dimaksudkan itu ialah 'Lingkungan Kesemakmuran Asia Timur Raya' atau 'East Asia Co-prosperity Sphere' yang meliputi seluruh kawasan Asia bagi menentang penjajah Barat sejak tahun 1936 lagi. ${ }^{1}$

Dr. Burhanuddin berharap ungkapan yang diuar-uarkan oleh pihak Jepun yang bangsa Asia perlu bangkit menentang penjajahan British dan mengagung-agungkan bangsa mereka sebagai bangsa dari Asia yang 
berjaya mengalahkan kuasa Barat iaitu Rusia dalam Perang Jepun-Rusia dalam tahun 1904-1905 menjadi kenyataan. ${ }^{2}$ Melalui kerjasama tokoh politik zaman silam ini dengan pihak pemerintah Jepun telah memberi 'manfaat' kepada Dr. Burhanuddin apabila diberi kepercayaan oleh pihak tentera Jepun memegang jawatan sebagai Penasihat Hal Ehwal Agama dan Adat Istiadat Melayu Jepun di Taiping, Perak.

\section{Penglibatan Semasa Zaman Pendudukan Jepun: Nasionalisme dan Politik}

Seperti diterangkan di awal tadi, zaman pendudukan Jepun telah meninggalkan kesan yang mendalam kepada Dr. Burhanuddin dalam kegiatan politik dan semangat nasionalismenya kepada masyarakat Melayu dan tanah airnya sendiri. Selain Ibrahim $\mathrm{Hj}$. Yaakob, beliau adalah seorang tokoh nasionalis Melayu yang memainkan peranan penting di zaman perang ini. Tokoh-tokoh Melayu lain seperti Ishak Hj. Mohamad (Pak Sako) dan Ahmad Boestamam agak kurang aktif kegiatan mereka dalam politik semasa Perang Dunia Kedua kerana mereka baru dibebaskan setelah dipenjarakan dan masing-masing menjalani kegiatan sendiri. Misalnya, Pak Sako berada di Singapura dan menjadi wartawan di akhbar Malai Syimbun iaitu sebuah akhbar pro Jepun. ${ }^{3}$

Ibrahim $\mathrm{Hj}$. Yaakob pula yang menerajui Kesatuan Melayu Malaya (KMM) dan aktif dalam politik di zaman Jepun telah menaikkan nama Dr. Burhanuddin di mata pihak Jepun. Beliau menyedari ketokohan doktor homeopati itu sebagai pemimpin politik Melayu yang cukup berkebolehan dan tidak teragak-agak memberi peluang kepada Dr. Burhanuddin berkolaborasi dengan pihak tentera Jepun disebabkan propaganda yang dilemparkan oleh mereka itu untuk menghalau penjajah Barat dari tanah air serta kawasan lain di Asia Tenggara. Oleh sebab itulah Dr. Burhanuddin merasakan yang kemasukan tentera Jepun ke Tanah Melayu dapat membuka peluang mencapai kemerdekaan bersama-sama dengan Indonesia. Tanpa disedari, tujuan sebenar pihak Jepun yang menjajah negara-negara di Asia, lebih-lebih lagi Tanah Melayu adalah untuk mengaut kekayaan dari tanah jajahannya bagi kepentingan pihak Jepun sendiri. ${ }^{4}$ Menurut satu kenyataan:

Mengikut rancangan ini, Tanah Melayu akan diletakkan di bawah pemerintahan Jepun sebagai sebahagian empayar Jepun dan negerinegeri Melayu akan dipimpin oleh sebuah badan penyediaan pentadbiran tentera. ${ }^{5}$

Melalui hubungan baik Dr. Burhanuddin dengan Ibrahim dalam perjuangan politik ketika dalam KMM serta sifat mempercayai kebolehan Dr. Burhanuddin, Ibrahim Hj. Yaakob mencalonkan Dr. Burhanuddin 
kepada pihak tentera Jepun bagi memegang jawatan Penasihat Adat Istiadat dan Kebudayaan Melayu di Markas Jepun di Taiping. ${ }^{6}$ Kepercayaan ini diberi bagi memberi peluang kepada Dr. Burhanuddin menunjukkan kebolehannya dalam perjuangan kerana di dalam KMM, Dr. Burhanuddin tidak memegang apa-apa jawatan penting parti. Dengan jawatan yang diberikan itu menunjukkan yang beliau perlu menjadi perantaraan antara pihak tentera Jepun dengan bangsa Melayu dalam urusan agama, adat serta sedikit yang berkaitan politik. Malah, dengan memegang jawatan itu juga beliau diberi ruang untuk mengemukakan pelbagai cadangan dan pandangan kepada pihak pemerintah ketenteraan Jepun.

Oleh yang demikian, Dr. Burhanuddin tidak menerima apa-apa tekanan yang berat daripada pihak penjajah Asia itu atas dasar 'sikap berbaik-baik' itu. Walau bagaimanapun, beliau menyedari yang pihak tentera Jepun banyak melakukan kekejaman dan siksaan kepada masyarakat Melayu. ${ }^{7}$ Atas kesedaran itulah beliau mengambil peluang melalui jawatannya itu untuk 'memujuk dan menasihati' penjajah Timur itu supaya tidak melakukan kekejaman dan tidak memaksa orang-orang Melayu dihantar ke Burma bagi membina landasan kereta api maut. ${ }^{8}$

Jawatan yang dipegang oleh beliau bukanlah untuk menyaingi atau menidakkan tugas Raja-raja Melayu sebagai ketua negeri Melayu dan peranan yang dilakukan baginda Sultan sebagai ketua agama Islam dan adat istiadat Melayu. ${ }^{9}$ Tugas Raja-raja Melayu sebagai ketua agama adalah secara langsung daripada baginda terus kepada masyarakat Melayu dan mempunyai kuasa lebih besar termasuk menghakimi undang-undang. Berbanding dengan bidang tugas Dr. Burhanuddin terlalu sempit dan hanya menjadi tempat rujukan dan penasihat kepada pihak tentera Jepun dalam hal ehwal Islam dan Melayu di Taiping sahaja, bukan di seluruh tanah air. Seharusnya beliau layak memegang jawatan itu kerana Dr. Burhanuddin berpendidikan agama, mempunyai semangat ke-Melayuan yang tinggi dan berpendidikan perubatan homeopati. Semasa menjalankan tugasnya di Taiping, semangat nasionalisnya semakin menonjol apabila beliau mempunyai hubungan yang baik dengan Ustaz Abu Bakar al-Baqir yang mengetuai sebuah sekolah agama, Madrasah Il- Ihya Gunung Semanggol di utara Taiping. ${ }^{10}$ Sebelum tentera Jepun menjajah Tanah Melayu, madrasah ini menjadi markas nasionalis Melayu berpendidikan agama. Oleh itu, peranan yang dimainkan oleh Dr. Burhanuddin sebagai pegawai khas pihak pemerintah Jepun, sekurang-kurangnya telah menyelamatkan madrasah ini daripada dicerobohi dan seterusnya menjadi markas tentera Jepun. Hubungan erat dua orang tokoh Islam ini telah memberi idea untuk mereka berunding dengan pihak tentera Jepun memberi kemerdekaan kepada tanah air pada bulan Ogos $1945 .{ }^{11}$ 
Pelantikan Dr. Burhanuddin memegang jawatan ini turut memberi beberapa keistimewaan peribadi kepada beliau apabila kerap diraikan oleh masyarakat Melayu kampung setiap kali melakukan lawatan kerja ke kawasan kampung Melayu. Dalam masa yang sama juga kehidupan keluarganya turut merasai sedikit keselesaan terutama bekalan beras sentiasa dihantar oleh pihak tentera Jepun ke rumahnya. ${ }^{12}$ Beliau juga mengambil kesempatan daripada kesenangan yang diterimanya dengan menghulur setengah keperluan bekalan beras kepada jiran-jiran sekelilingnya secara diam-diam tanpa pengetahuan pihak tentera kerana bekalan makanan menjadi masalah utama kepada penduduk Tanah Melayu pada zaman perang itu. ${ }^{13}$

Menurut seorang sahabatnya, setiap kali melakukan lawatan dan singgahan ke kampung-kampung sekitar Taiping, Dr. Burhanuddin akan memberi kata-kata perangsang bagi menghadapi kesusahan akibat peperangan dan seterusnya menaikkan semangat nasionalisme kepada bangsa Melayu. ${ }^{14}$ Beliau perlu bertindak sebegitu kerana menyedari pihak pemerintah Jepun mempunyai sikap berpura-pura dan tidak ikhlas memberi kemerdekaan dalam tempoh terdekat. Namun, Dr. Burhanuddin terpaksa melakukan kerjasama dengan mereka atas beberapa sebab, terutama sekali kejayaan pihak tentera Jepun menghalau penjajah British dari tanah air. Berkaitan dengan hal ini, Dr. Burhanuddin ada menyatakan dalam satu tulisan, iaitu:

Kekejaman, kebengisan, kedurjanaan, kezaliman facis Jepun tiada siapa yang tidak kenal dan tidak perlu dituliskan pemerintahan tangan besi Firaun kurun dua puluh. Gerakan kebangsaan diharamkan sama sekali oleh Jepun. Maka ahli-ahli kebangsaan Melayu kiri telah mengambil langkah Musa dalam istana Firaun. Ada yang tinggal di dalam, ada yang tinggal di luar mengambil bahagian di hutan rimba jadi antifacis ada yang menjalankan gerakan rayap semut putih, harimau dan sebagainya... ada pula yang memasukkan diri dalam Bintang Tiga, Communist Party, Anti-Facist dan lain lain... kesedaran dan kemarahan kebangsaan Melayu bertambah berbangkit dengan sebab pekerti Jepun menyerahkan empat buah negeri Melayu kepada Thai. ${ }^{15}$

Menerusi keterangannya itu, beliau telah menyedari niat sebenar pihak Jepun dalam 'membantu' negara Asia yang dijajah Barat. Hal ini berlaku adalah disebabkan pihak pemerintah Jepun mengharam sebarang parti politik dan menutup ruang untuk rakyat bergerak melalui semangat nasionalisme. Misalnya, KMM diharamkan serta merta dalam kegiatan politik dan nasionalisme. ${ }^{16}$ Mana-mana golongan radikal yang giat menjalankan aktiviti politik dan semangat nasionalisme menerima tekanan teruk oleh pihak tentera. Dari kenyataan itu menunjukkan yang Dr. 
Burhanuddin memahami yang pihak Jepun mempunyai hasrat yang sama seperti British dan Belanda iaitu menjajah. Apabila berlaku sebarang bentuk penjajahan akan berlaku juga segala bentuk kekejaman dan penindasan terhadap bangsa yang dijajah seperti apa yang terjadi di Tanah Melayu. Oleh itu, semasa pendudukan Jepun juga sistem pentadbiran Tanah Melayu dipecah kepada dua dan menggabungkan pentadbiran dengan Sumatera. Wilayah-wilayah di sebelah utara, iaitu Perlis, Kedah, Kelantan dan Terengganu diserah kepada pemerintahan Siam pada 18 Oktober $1943 .{ }^{17}$ Berlakunya hal ini adalah disebabkan pihak pemerintahan Jepun mahu membalas budi baik kerajaan Siam yang membenarkan penggunaan wilayahnya di bahagian selatan sebagai pintu masuk tentera-tentera Jepun ke Tanah Melayu. ${ }^{18}$

Berbalik kepada pengharaman KMM, para golongan kiri terpaksa menerima hakikat yang parti Melayu haluan kiri itu tidak boleh bergerak cergas langsung dalam politik dan nasionalisme tanah air. Namun begitu, Mustapha Hussein yang pernah menjadi pemimpin nombor dua KMM, menuntut daripada pihak tentera Jepun mengotakan segala janji iaitu memberi kemerdekaan penuh kepada Tanah Melayu. ${ }^{19}$ Tuntutan Mustapha tersebut disebabkan peranan KMM dalam membantu pihak tentera Jepun memasuki Tanah Melayu dengan niat menghalau penjajah British. ${ }^{20}$ Selain itu, Mustapha juga kecewa dengan sikap Ibrahim $\mathrm{Hj}$. Yaakob yang membelakanginya dalam beberapa urusan dalam KMM dan perjuangan kemerdekaan. Beliau meluahkan perasaannya yang Ibrahim Hj. Yaakob hanya mencarinya jika diperlukan. ${ }^{21}$

Walau bagaimanapun, pendirian Dr. Burhanuddin tidak sama dengan golongan radikal lain sekalipun mereka berada dalam satu parti, iaitu KMM. Jika beliau memilih jalan untuk berkompromi dengan pihak tentera Jepun, rakan seperjuangannya yang lain terutama Mustapha berjuang melawan pihak Jepun dalam hutan kerana merasa kecewa dengan janjijanji kosong pemerintah tentera Jepun itu. ${ }^{22}$ Berlakunya keadaan ini mungkin disebabkan Dr. Burhanuddin yakin yang pihak Jepun akan memberi kemerdekaan juga akhirnya bersama Indonesia di saat-saat akhir tamat peperangan tersebut. Seperti yang telah dinyatakan bahawa beliau dan Ibrahim 'cukup menghargai jasa-jasa' tentera Jepun yang mengusir pihak British di Tanah Melayu dan Singapura. Dengan kata lain, bukan kerana jawatan yang diberi serta keistimewaan kedudukan yang menyebabkan Dr. Burhanuddin terpaksa berbuat-buat baik dengan pihak Jepun. Beliau tetap menyedari tentang hal ini iaitu sebenarnya pihak Jepun turut melibatkan diri sebagai penjajah.

Dasar bekerjasama dengan pihak pemerintah Jepun telah memberi ruang untuk Dr. Burhanuddin mengadakan satu kongres yang agak besar pada masa itu. Kongres yang bekerjasama dengan pihak penjajah Asia 
Timur itu adalah satu perhimpunan yang membincangkan tentang hal ehwal agama Islam serta menyatukan persaudaraan sesama agama dan bangsa yang turut dihadiri oleh peserta dari Sumatera. Kongres yang berlangsung pada tahun 1944 itu telah mencapai matlamatnya. Walaupun kongres ini berlandaskan isu-isu ke-Islaman, tidak dapat tidak diselitkan juga isu-isu nasionalisme, anti penjajahan dan kemerdekaan yang akhirnya berjaya dikesan oleh pihak pemerintah Jepun. Apabila pihak Jepun mengetahui keadaan itu, kongres seterusnya yang bakal berlangsung gagal diadakan. Pihak Jepun merasa bimbang jikalau tidak dipantau kongres kedua akan menjadi pusat kegiatan nasionalisme masyarakat Islam. ${ }^{23}$

Semasa pendudukan Jepun ini, Dr. Burhanuddin bekerja keras dalam usaha untuk memerdekakan Tanah Melayu bersama-sama dengan Indonesia melalui hasrat dan cita-citanya dalam ideologi politiknya melalui 'Gagasan Melayu Raya'. ${ }^{24}$ Pada pemikiran Dr. Burhanuddin, kemerdekaan dua wilayah ini menjadi satu harapan kerana mempunyai budaya, bahasa dan agama yang sama yang merangkumi dunia Melayu. Menurut beliau, inilah peluangnya untuk mendapat kemerdekaan bersama-sama melalui bantuan pihak Jepun selepas British dan Belanda telah keluar daripada Tanah Melayu dan Indonesia. Lebih-lebih lagi pihak pemerintah Jepun bersetuju memerdekakan kedua-dua wilayah serumpun ini melalui propaganda-propaganda yang dilemparkan sebelum menjajah seluruh Asia Tenggara kecuali Siam. ${ }^{25}$ Malah, penasihat pihak tentera Jepun bagi Asia Tenggara, Profesor Itagaki membenarkan Ibrahim berunding dengan pihak Jepun, para pemimpin politik dan nasionalis Indonesia yang diketuai oleh Sukarno. Melalui Ibrahim dan dibantu oleh Dr. Burhanuddin, pertemuan telah diatur dengan pemimpin-pemimpin Indonesia tersebut untuk membincangkan supaya Tanah Melayu dimasukkan bersama-sama dalam kemerdekaan Indonesia. Rombongan kemerdekaan telah pergi ke Indonesia pada bulan April 1945 untuk berunding bersama-sama. ${ }^{26}$

Pada mulanya usaha para nasionalis kedua-dua wilayah itu hampir menampakkan hasil apabila Sukarno membawa usul memasukkan Tanah Melayu dalam kemerdekaan Indonesia dalam mesyuarat Badan Penyelidik Usaha Persiapan Kemerdekaan Indonesia yang dibentuk pada 28 Mei 1945..$^{27}$ Melalui badan ini, kata putus dan usul yang dikemukakan oleh pemimpin ulung Indonesia itu telah dipersetujui kemasukan Tanah Melayu dengan bermatlamat untuk faedah keselamatan dan kedaulatan politik Indonesia. Seterusnya pada 12 dan 13 Ogos 1945, pertemuan lebih lanjut diadakan di Taiping yang turut dihadiri oleh Dr. Burhanuddin sendiri bersama-sama Ibrahim, Sukarno dan Mohamad Hatta dalam usaha untuk membincangkan soal-soal kemerdekaan 'Indonesia Raya'. ${ }^{28}$ Kedatangan dua orang pemimpin nasionalis Indonesia itu ke Taiping adalah secara kebetulan kerana mereka dalam perjalanan pulang dari Saigon, Vietnam 
untuk bertemu dengan Ketua Turus Agung Tentera Jepun bagi Asia, Field Marsyal Count Terauchi. Dalam pertemuan tersebut mereka telah berbincang, mencapai kata sepakat dan membuat perjanjian, antaranya ialah: ${ }^{29}$

Kemerdekaan Tanah Melayu turut bersatu dengan Indonesia, perisytiharan kemerdekaan akan diumumkan pada penghabisan bulan itu (Ogos), dan Tanah Melayu akan menghantar lapan perwakilan delegasi ke Jakarta untuk turut mengisytiharkan kemerdekaan dan pembentukan pemerintahan sementara negara Republik Indonesia sekali dengan Tanah Melayu.

Lanjutan pertemuan itu telah memberi idea kepada Ibrahim serta Dr. Burhanuddin menubuhkan Kesatuan Rakyat Indonesia Semenanjung (KRIS) dalam tahun yang sama. ${ }^{30}$ Sebenarnya KRIS dan KMM adalah sama dari segi dasar politik, nasionalisme dan keanggotaannya. KRIS telah menganjurkan satu persidangan pemuda-pemudanya dalam usaha untuk menyemai sokongan memerdekakan tanah air. Persidangan yang diadakan pada bulan 15 Ogos 1945 di Station Hotel, Kuala Lumpur telah dihadiri oleh wakil-wakil pemuda Melayu dari seluruh Tanah Melayu, Kepulauan Riau-Lingga dan selatan Siam. ${ }^{31}$ Kongres ini telah memutuskan beberapa keputusan iaitu:

(a) Perjuangan kemerdekaan bersama Indonesia wajib diteruskan dengan IBHY (Ibrahim Hj. Yaakub), Onan Siraj, Hassan Manan dan Ramly Tahir diutus ke Jakarta (Sdr. Ramly tak jadi).

(b) Kongres KRIS 16-17 Ogos diserahkan kepada Dr. Burhanuddin memimpinnya bersama Hassan Manan, Dato' Onn, Tengku Hussein-Singapura dan lain-lainnya.

(c) IBHY, Onan Siraj dan Ramly Tahir dikehendaki ke Singapura malam 15.8.45 itu juga untuk mengurus delegasi ke Jakarta, sepasukan Giyu Gun dikirim ke Kuala Lumpur untuk bersama MPAJA melawan tentera Inggeris.

(d) Pagi pukul 2.00 pada 17.8.1945 kami bertiga sampai di Singapura terus berunding dengan wakil MPAJA Singapura di Tiong Bharu yang masih bersetuju Giyu Gun dikirimkan ke Kuala Lumpur. ${ }^{32}$

Melalui pengasasan KRIS ini, penerusan cita-cita dan matlamat bagi kemerdekaan bersama di samping merancang strategi bagi menghalang kemasukan semula British ke Tanah Melayu, mengelakkan penguasaan Malayan People's Anti-Japanese Army (MPAJA) serta menangkis dakwaan yang menuduh KRIS sebagai tali barut Jepun. Bagi mengukuhkan pertahanan tanah air, Dr. Burhanuddin mengemukakan cadangan supaya pemuda-pemuda Melayu yang pernah dilatih oleh pihak tentera Jepun 
dalam pelbagai jenis latihan ketenteraan, diserapkan menjadi tentera penentang kemasukan balas tentera British ke Tanah Melayu selepas berakhirnya perang dunia kedua pada bulan September $1945 .{ }^{33}$

Hasrat Dr. Burhanuddin mencapai kemerdekaan Tanah Melayu bersama-sama dengan Indonesia hampir menampakkan hasilnya kerana kesediaan Sukarno dan Hatta menerima kemerdekaan bersama. Walau bagaimanapun, hasrat untuk mencapai kemerdekaan bersama-sama dengan wilayah jiran, Indonesia tidak kesampaian dan menemui kegagalan. Kebuntuan mencapai kemerdekaan bersama-sama itu disebabkan pihak Jepun tidak dapat melaksanakan janjinya di saat-saat akhir yang ketika itu pihak tenteranya mengalami kekalahan teruk dalam perang dengan kuasakuasa Berikat yang dimonopoli oleh British dan Amerika Syarikat. ${ }^{34}$ Beliau memperolehi berita buruk itu daripada Itagaki. Pegawai tentera Jepun itu memberitahu lagi bahawa pihak Jepun telah menyerah diri kepada kuasa Berikat pada 15 Ogos 1945 setelah pengeboman atom di Hiroshima dan Nagasaki. Sejurus selepas itu, para nasionalis Indonesia mengisytiharkan kemerdekaan tanah air mereka secara tergesa-gesa pada 17 Ogos 1945 tanpa memberitahu pemimpin radikal Melayu yang lain. ${ }^{35}$ Sehari sebelum itu KRIS telah dibubarkan semasa kongresnya di Kuala Lumpur. Pembubaran itu adalah seiring dengan kekalahan Jepun.

Kembali kepada Ibrahim Hj. Yaakob, beliau bertindak bijak berhijrah ke Jawa demi keselamatan dirinya dan keluarganya supaya tidak menerima sebarang tekanan atau hukuman daripada pihak British yang datang kembali ke Tanah Melayu. ${ }^{36}$ Beliau lari ke sana dengan bantuan pihak tentera Jepun pada 19 Ogos 1945 bersama-sama sahabat seperjuangannya, Hassan Manan serta ahli keluarganya tanpa membawa Dr. Burhanuddin bersama-samanya. Oleh itu, dapat dikatakan bahawa Ibrahim telah meninggalkan sisa-sisa perjuangannya kepada Dr. Burhanuddin dan pejuang kemerdekaan lain tanpa meninggalkan sebarang arahan dan amanat perjuangan parti dan KRIS, pada hal dasar KRIS dibuat oleh Ibrahim tetapi yang menjalankan tugas adalah Dr. Burhanuddin sendiri.

\section{Kesimpulan}

Dengan kegagalan ini, sudah semestinya mengecewakan Dr. Burhanuddin apabila matlamat untuk memerdekakan tanah airnya tidak sampai ke penghujung. Sebagai seorang pejuang kemerdekaan, perjuangannya tidak pernah putus. Setiap kali tulisan-tulisan dan ucapan-ucapan politiknya, Dr. Burhanuddin tidak menunjukkan nada-nada kekesalan kerana baginya perjuangan kemerdekaan Tanah Melayu mesti diteruskan. Selepas pendudukan Jepun dan pihak British kembali ke Tanah Melayu dan tanah air mencapai kemerdekaan, penglibatan Dr. Burhanuddin dalam arena politik dan perjuangan nasionalismenya tidak berhenti begitu sahaja. Beliau 
terus aktif dalam PKMM, Parti Islam Se-Tanah Melayu (PAS) dan menjadi ahli parlimen setelah memenangi kerusi tersebut di Besut, Terengganu dalam pilihanraya umum pada tahun 1959. Oleh itu, dapat dikatakan selepas tahun 1945, penglibatan dan perjuangan Dr. Burhannudin semakin menonjol dan tidak pernah kenal erti penat serta kalah di medan politik. Suara-suaranya nyaring didengari dalam dewan persidangan Parlimen Persekutuan Tanah Melayu dan isu-isu yang diperdebatkan sering mendapat perhatian ahli-ahli dewan sehinggalah beliau ditangkap di bawah Akta Keselamatan Dalam Negeri (ISA).

\section{Nota}

${ }^{1}$ Menurut Toru Yana, 'Lingkungan Kesemakmuran Asia Timur Raya' meliputi China, Utara Sakhalin, Manchuria, Kuriles, Timur Siberia, Mongolia Luar, Mongolia Dalam, Tiber, kepulauan jajahan Jerman di Pasifik, Indochina, Burma, Australia, New Zealand, India, Filipina serta negara mereka sendiri, Jepun. Lihat, Toru Yana, "Greater East Asia Co-Prosperity, Sphere: Setting the Stage for the Cold War in Southeast Asia", dalam Seminar 'The International Environment in Post War Asia, Kyoto, November, 1975, hlm. 12.

2 Peperangan ini berlangsung pada 10 Februari 1904 hingga 5 September 1905. Konflik persaingan antara Rusia dengan Jepun di Manchuria Selatan dan Korea. Sebab utama berlaku persengketaan tersebut ialah merebut Port Arthur di Semenanjung Liaodong. Dengan kemenangan itu, pihak Jepun menunjukkan kebangkitan kuasa dan kekuatan Asia menandingi kekuasaan Barat. Negara Jepun menjadi kuasa baru dalam pertahanan dan politik. Kesannya memberi kebangkitan nasional kepada wilayah-wilayah yang dijajah oleh Barat. Keterangan lanjut, rujuk Clan Nish, The Origins of the Russo-Japanese War, Longman, 1985.

${ }^{3}$ Mendalami kisah sejarah kehidupan dan perjuangan beliau, rujuk, Ishak Haji Muhammad, Memoir Pak Sako: Putera Gunung Tahan, Bangi: Penerbit Universiti Kebangsaan Malaysia, 1997; Ishak Haji Muhammad, Pengalaman Pak Sako tiga tahun di Singapura, Petaling Jaya: Pustaka Budaya Agency, 1975; dan, Ishak Haji Muhammad, Catatan Pengalaman Pak Sako, Petaling Jaya: Binakarya, 1987.

${ }^{4}$ British Intelligence Report, File Code F1, A.P.I. Lihat juga, David Bergamin, Japan Imperial Conspiracy, London: Heinemann, 1971, hlm. 569; dan, Eric Robertson, The Japanese File, Hong Kong: Heinemann, 1979.

5 Yoji Akashi, "Japanese Military Administration in Malaya - Its Formation and Evolution in Reference to Sultans, the Islamic Religion, and the Moslem-Malaya, 1942-1945", dlm. Asian Studies, 7, No. 1, April 1969, hlm. 82.

6 Mengikut satu sumber, Mustapha $\mathrm{Hj}$. Hussain yang sebenarnya memilih beliau untuk menjawat jawatan tersebut. Menurut Mustapha; "Saya telah memilihnya untuk menyandang jawatan Pembantu (mula-mula) dalam Jabatan Hal Ehwal Orang-Orang Melayu dalam sebuah Jabatan Pemerentah Jepun bernama Gunseikanbu di Singapura (Syonan diwakhtu itu) oleh kerana beliau berkaliber yang payah dicari-progressive dalam agama, fasih dalam bahasa A rab, tahu bahasa Inggeris dan yang terlekat pada hati saya ialah kerana ia pernah merengkok dalam lokap Polis 
Singapura kerana membantah diatas persetujuan British memberi tempat kepada Yahudi di Palestin".

Petikan dari SP/84, Alias Hj. Zaidi, "Dr. Burhanuddin al-Helmi Pelopor Kebangkitan Semangat", dlm. Mastika, Disember, 1979. Sumber Arkib 2007/ 0026349.

Ibrahim Hj. Yaakob pula dilantik sebagai Penasihat Hal Ehwal Sumatera/Tanah Melayu Kepada Pentadbiran Tentera Jepun di Singapura pada bulan Ogos 1942. Dengan jawatan yang dipegangnya itu, beliau mengetuai satu Lembaga Penasihat Melayu dengan enam orang anggota yang dipilihnya. Walau bagaimanapun, pihak Jepun tetap tidak melepaskan bangsa Melayu dengan begitu sahaja tanpa diawasi. Untuk tujuan itu, pegawai tentera Jepun, Hosai yang berpangkat Kolonel telah dilantik kepada Setiausaha kepada Ibrahim Haji Yaakob.

7 Antara kekejaman yang dilakukan oleh tentera Jepun ke atas penduduk tempatan adalah seperti menggertak, memaksa memanjat pokok kelapa, minum air bertimba-timba, memukul dan menekan perut dengan papan. Lihat kekejaman yang dilakukan mereka itu dalam, Baharum Ahmad, Syair Kenang-kenangan, Pulau Pinang: The Ltd. Press, 1952.

8 Kenyataan Hj. Abdul Majid Salleh ketika ditemubual pada 10, 23 dan 30 September 2007, di rumahnya di Kampung Sengat, Gopeng, Perak.

9 Keterangan lanjut tentang perkara ini, sila rujuk, Yoichi Itagaki; "Some Aspects of the Japanese Policy for Malaya Under the Japanese Occupation, with Special Reference to Nationalism", dlm. K.G. Tregonning [ed.], Papers on Malayan History, Singapura, 1962, hlm. 257. Sebelum pendudukan Jepun, kedudukan sultan adalah sebagai ketua agama Islam dan sebagai pemimpin politik masyarakat Melayu. Ini bermakna sultan adalah ketua negeri dan penaung kepada agama Islam dan adat istiada masyarakat Melayu. Pada bulan September 1942, pihak Jepun membuat pindaan iaitu gelaran sultan diiktiraf tetapi hanya dianggap sebagai ketua agama Islam dan adat istiadat Melayu dan bukannya ketua negeri. Oleh yang demikian, jumlah elaun dan pencen politik dikurangkan separuh daripada jumlah sebelum perang. SUK/K86/2602; dan, BMA/ADM/9/27. Translation Report 33. Rujuk juga, Mohamad Isa Othman, Pendudukan Jepun di Tanah Melayu 1942-1945 (Tumpuan di Negeri Kedah), Kuala Lumpur: Dewan Bahasa dan Pustaka, 1992, hlm. 36-37; dan Abdullah Zakaria Ghazali, Pentadbiran Tentera Jepun Dan Thai Di Terengganu, Kuala Lumpur: Penerbit Universiti Malaya, 1996.

${ }^{10}$ Untuk mengetahui lebih lanjut tentang tokoh ini, lihat, Khairul Nizam Zainal Badri, Ketokohan dan Pemikiran Abu Bakar Al-Bagir, Shah Alam: Karisma, 2008. Rujuk juga, akhbar Majlis, 1947.

${ }^{11}$ Nabir bin Abdullah, Maahad Il Ihya Assyarif Gunung Semanggol 1934-1959, Kuala Lumpur: Universiti Kebangsaan Malaysia, 1976, hlm. 89.

12 Kenyataan Norbait Mohd Noor, pada 6 September 2008, di Taman Senu, Sentul, Kuala Lumpur.

${ }^{13}$ Kenyataan Hj.Abdul Majid Salleh.

${ }^{14}$ Ibid. 
${ }^{15}$ Dr. Burhanuddin al-Helmy, "Perjuangan Kita, 1946", dlm. Kamaruddin Jaafar, Dr. Burhanuddin: Islam Dan Kebangsaan, Kuala Lumpur: Yayasan Anda, 1980, hlm. 42.

${ }^{16}$ KMM didaftarkan secara rasmi pada Disember 1940 tanpa ada perlembagaan dan senarai ahli jawatan kuasa sendiri. Ibu pejabat KMM di Kuala Lumpur dengan ahli sekitar 50,000-60,000 orang. Lihat (W. R. Roff, The Origins of Malay Nationalism, Kuala Lumpur: Pustaka Ilmu, University of Malaya Press, 1967). Lidah rasmi KMM ialah Majlis. Menurut Mustapha Hussein, KMM diharamkan oleh pihak Jepun pada bulan Mac 1942. Lihat, Harry J Benda, et.al., (eds.), "Document No. 1, Principles Governing The Administrator of Occupied Southern Areas", dlm. Japanese Administration in Indonesia: Selected Document, Yale, Southeast Asia Studies, 1965, hlm. 1.

${ }^{17}$ Fail SUK(Tr) 109/1361, "Pemberitahuan Kerajaan", bil. 5/2486, Pejabat Maklumat, 1.11.2486; Fail SUK(K) 243-2603; dan, Syonan Syimbun, 21 Ogos 2603 [1943]. Lihat juga, Mohammad Muzammil bin Mohammad Noor, Guru Melayu Di Kedah: Penglibatan Dalam Politik, 1940-1960, Tesis Sarjana Sastera, Universiti Sains Malaysia, 2005, hlm. 90-106. Bagi melihat kerjasama Siam membantu tentera Jepun menakluki Tanah Melayu melalui satu perjanjian, lihat, SUK (Tr) 51/2603, "Cabutan Daripada Berita Malai", 21 Ogos 2603.

${ }^{18}$ BMA/ADM 327/46-5 th Column: Intelligence Reports, Malaya Command And Formations Under Command, 1946.

${ }^{19}$ Rujuk sejarah penglibatan Mustapha di zaman pendudukan Jepun dalam buku memoirnya, Memoir Mustapha Hussain Kebangkitan Nasionalisme Melayu Sebelum UMNO, (Penyel. Insun Sony Mustapha), Kuala Lumpur: Dewan Bahasa dan Pustaka, 1999, hlm. 228-396.

${ }^{20}$ Lihat, Cheah Boon Kheng, Red Star Over Malaya, Singapura: SUP, 1983, hlm. 115-123; Cheah Boon Kheng, "The Japanese Occupation of A Malaya, 1941-1945: Ibrahim Yaacob And The Struggle For Indonesia Raya", dlm. Indonesia, no. 28, 1979, hlm. 90-97; serta, Mohamad Isa Othman, Pendudukan Jepun di Tanah Melayu 1942-1945 (tumpuan di Negeri Kedah), Kuala Lumpur: Dewan Bahasa dan Pustaka, 1992, hlm. 2-3.

${ }^{21}$ Syonan Syimbun, Singapura, 30 Julai 1943. Lihat juga luahan perasaan Mustapha dalam Memori Mustapha Hussain Kebangkitan Nasionalisme Melayu Sebelum UMNO.

${ }^{22}$ Dr. Burhanuddin dan Mustapha merupakan dua orang rakan seperjuangan berhaluan kiri. Mereka terlibat bersama dalam parti politik anti British iaitu KMM. Semasa zaman Perang Dunia Kedua, mereka berubah haluan masingmasing dalam perjuangan iaitu Dr. Burhanuddin bekerjasama dengan pihak tentera Jepun dan Mustapha mengambil keputusan menentang sebarang bentuk penjajahan termasuklah penjajahan Jepun.

${ }^{23}$ Rujuk, N.J. Funston, Malay Politics in Malaysia A Study of UMNO and PAS, Petaling Jaya: Heinemann Educational Books [Asia] Ltd, 1980, hlm. 119.

${ }^{24}$ Rujuk, Dr. Burhanuddin, Sejarah (Perjuangan Kita), [jawi]; Dr. Burhanuddin Al-Helmy, "Falsafah Kebangsaan Melayu, 1954", dlm. Kamaruddin Jaffar, Dr. Burhanuddin Al-Helmy Pemikiran dan Perjuangan, hlm. 31-63, dan hlm. 68122; dan, C.O. 531/2177-Indonesia Influence the Malay Peninsular, Part 1, "Among the Malays", hlm. 23. Rujuk juga, Pelita Malaya, 1 April 1946, dan 5 April 1946. 
${ }^{25}$ Keterangan lanjut, rujuk Toru Yana, "Greater East Asia Co-Prosperity, Sphere: Setting the Stage for the Cold War in Southeast Asia", hlm. 12. Selain itu, janjijanji pihak Jepun bagi memerdekakan Tanah Melayu boleh dirujuk di British Intelligence Report, File Code F1, A.P.I. Lihat juga, David Bergamin, Japan Imperial Conspiracy, hal. 569; dan, Eric Robertson, The Japanese File.

${ }^{26}$ Mohamad Yamin, Naskhah Persiapan Undang-undang Dasar 1945, Jil. 1, Jakarta: Jajasan Prapantja, 1954, hlm. 206-212.

${ }^{27}$ SP/89/112 - Siaran 26.7.1945, Persetujuan Jepun Untuk Memerdekakan Tanah Melayu.

${ }^{28}$ Ibid.

${ }^{29}$ Ibid.

${ }^{30}$ Untuk keterangan lanjut tentang penubuhan KRIS, sila lihat tulisan Ibrahim $\mathrm{Hj}$. Yaakob dalam bukunya sendiri yang bertajuk Sekitar Malaya Merdeka, serta Melihat Tanah Air, Kota Bharu: Al-Islamiah Press, 1941. Dalam tulisan Cheah Boon Kheng pula, KRIS dirujuk sebagai Kerajaan Rakyat Indonesia Semenanjung. Cheah Boon Kheng, Red Star Over Malaya, hlm. 327.

${ }^{31}$ Ramlah Adam, Burhanuddin Al-Helmy Suatu Kemelut Politik, Kuala Lumpur: Dewan Bahasa dan Pustaka, 1996, hlm. 27.

${ }^{32}$ Surat Ibrahim Hj. Yaakob kepada Mustapha Hussain, bertarikh 20 Mei 1975, hlm. 3.

${ }^{33}$ Penjelasan daripada sahabat seperjuangan beliau, Hj. Abdul Majid Salleh ketika ditemubual.

${ }^{34}$ SP/89/112 - Siaran 26.7.1945, Persetujuan Jepun Untuk Memerdekakan Tanah Melayu.

${ }^{35}$ Pengisytiharan kemerdekaan Indonesia berlangsung pada hari Jumaat, 17 Ogos 1945 yang dilakukan oleh Ir. Sukarno yang disaksikan oleh Mohammad Hatta di Jalan Pegangsaan Timur 56, Jakarta Pusat. Keterangan lanjut tentang pengisytiharan kemerdekaan negara itu, sila lihat, Soekarno, Tetap terbanglah, radjawali!: Pidato P.J.M. Presiden Republik Indonesia pada hari ulang tahun ke sepuluh proklamasi kemerdekaan Indonesia 17 Agustus 1955, Djakarta: Kementerian Penerangan Republik Indonesia, 1955; dan Adam Malik, Riwajat dan perdjuangan sekitar proklamasi kemerdekaan Indonesia, 17 Augustus 1945: diperlengkap oleh orang-orang jang langsung ikut menjelenggarakan proklamasi 17 Augustus 1945, Djakarta: Widjaya, 1950. 